\title{
Shprintzen-Goldberg syndrome presenting as umbilical hernia in an Indian
} child

1 * Bhushan Shah, ${ }^{2 *}$ Suman Sahu, ${ }^{1}$ Piyush Kalakoti, ${ }^{1}$ Sankalp Yadav, ${ }^{1}$ M M Aarif Syed, ${ }^{3}$ Venugopal

\author{
Brijmohan Bhattad, ${ }^{1}$ Meena Shaikh
}

* Contributed equally to the work

${ }^{1}$ Department of General Surgery, Rural Medical College, Pravara Institute of Medical Sciences,

Loni, MH 413736, India; ${ }^{2}$ Hebei Medical University, Shijiazhuang, Hebei, China 050017; ${ }^{3}$ Topiwala

\section{National Medical College and BYL Nair Charitable Hospital, Mumbai.}

\section{CASE REPORT}

Please cite this paper as: Shah B, Sahu S, Kalakoti P, Yadav S, Syed MMA, Bhattad VB, Shaikh M. Shprintzen-Goldberg syndrome presenting as umbilical hernia in an Indian child. AMJ 2014, 7, 2, 51-57. http://doi.org/10.21767/AMJ.2014.1888

\section{Corresponding Author:}

Dr. Bhushan Shah

MBBS, MS (General Surgery)

Department of General Surgery

Rural Medical College, Pravara Institute of Medical Sciences, Loni, MH 413736, India

Email: drbhushanshah@gmail.com

\section{Abstract}

Shprintzen-Goldberg syndrome (S-G) is a rare connective tissue disorder characterised by craniosynostosis, craniofacial dysmorphism, skeletal, cardiovascular, neurological, and other abnormalities. We herein present a case of a five-year-old Indian child who presented to our clinic with reducible umbilical hernia since birth, mental retardation, and delayed developmental milestones. After meticulous clinical examination with subsequent integration of clinical findings and investigations, we diagnosed her to possibly have Shprintzen-Goldberg syndrome. An attempt to compare the findings of our index case with the classical features as described by Greally et al. has been made. Given the rarity of this syndrome and the paucity of medical literature measuring the magnitude of this condition in the Indian population, this case serves to promote awareness of this rare entity.

\section{Key Words}

Shprintzen-Goldberg syndrome; umbilical hernia; craniosynostosis; marfanoid habitus; Indian

\section{Implications for Practice:}

\section{What is known about this subject?}

Shprintzen-Goldberg syndrome is a rare connective tissue disorder characterised by craniosynostosis and marfanoid features with approximately 60 cases reported in literature since its first description in 1981 by Sugarman and Vogel.

\section{What is the key finding in this case report?}

An Indian child presenting with an umbilical hernia since birth, mental retardation, and delayed developmental milestones.

\section{What are the implications for future practice?}

A high degree of clinical suspicion is essential to diagnose a case of Shprintzen-Goldgerg syndrome should a patient present with a congenital umbilical hernia, along with features of craniosynostosis and marfanoid habitus. In addition, other life-threatening conditions associated with this syndrome, especially cardiac and musculoskeletal should not be missed while evaluating such patients.

\section{Background}

Shprintzen-Goldberg syndrome (S-G) is a rare congenital connective tissue disorder, characterised by craniosynostosis and marfanoid habitus. ${ }^{1}$ Patients with this syndrome have characteristic facial dysmorphism along with other abnormalities, including cardiovascular, musculoskeletal, neurologic, genitourinary, and others. ${ }^{2-4}$ We herein report a case of a five-year-old female child who presented to our clinic with umbilical hernia and delayed developmental milestones. She was later diagnosed to possibly have S-G syndrome based on the collaboration of peculiar clinical findings and subsequent investigations. The findings of our index case have been compared with the classical features of Shprintzen-Goldberg syndrome as described by Greally et al. ${ }^{1,4}$ (Table 1 ). We reported this case because of the syndrome's rarity and the paucity of medical literature measuring the magnitude of the condition in the Indian population. 


\section{Case details}

A five-year-old female child, born to non-consanguineous parents presented to our clinic with reducible umbilical swelling since birth, mental retardation, and delayed developmental milestones: initiated walking without support at 27 months; delayed speech and language onset at age three with an expressive and receptive language disorder; and a persistent nasal twang until age four. Her birth history includes a normal vaginal delivery at term with no known exposure to teratogens during perinatal life. Clinical examination revealed dolichocephaly, anteroposterior elongation of the skull, flattening of sides of head, mild proptosis, hypertelorism (Figure 1a), low set ears and micrognathia (Figure 1b), hyper extensible thumb (Figure 1c, 1d), reducible umbilical hernia (Figure 1e), hypotonia, pes planus with relatively long toes and talipes equinovarus associated with osteopenia (Figure 1f).

A strong suspicion of an underlying genetic condition was made. Routine blood investigations, including haemogram, coagulation profile, and liver and kidney function tests were within normal limits. Cerebrospinal fluid analysis was unremarkable. A radiograph of the skull revealed flattening of the cranial base and signs of craniosynostosis compatible with early synostosis of the sagittal suture. Ultrasound of the abdomen and pelvis was unremarkable except for an underlying defect of a non-strangulated, uncomplicated umbilical hernia. Chest roentgenogram was remarkable for 13 pairs of ribs (Figure 2a). An X-ray of the foot showed osteopenia with the loss of medial arches of the foot (Figures 2b, 2c).

A two-dimensional echo showed marked aortic root dilatation (Figure 2d). Karyotyping and genetic analysis could not be performed owing to the poor affordability of the parents. Considering various craniofacial, skeletal, cardiovascular, neurological, and other abnormalities ${ }^{1,4}$ (Table 1), well supported by clinical examination, radiographic findings and an extensive literature search, this case was provisionally diagnosed as Shprintzen-Goldberg syndrome. Differentials included Loeys-Dietz syndrome ${ }^{5,6}$, Marfan syndrome ${ }^{7}$, congenital contractural arachnodactyly $(\mathrm{CCA})^{8,9}$ Idaho syndrome-II, Antley-Bixler syndrome, and other craniosynostotic syndromes (Table 2).
Figure 1: Gross images showing characteristic features of the Shprintzen-Goldberg syndrome in our index case

(a) Hypertelorism, mild proptosis, flattening of sides of head; (b) low set of ears and mandibular micrognathia; (c) and (d) showing hyper extensible thumb and joint laxity; (e) umbilical hernia since birth; (f) pes planus with relatively large toes and talipes equinovarus

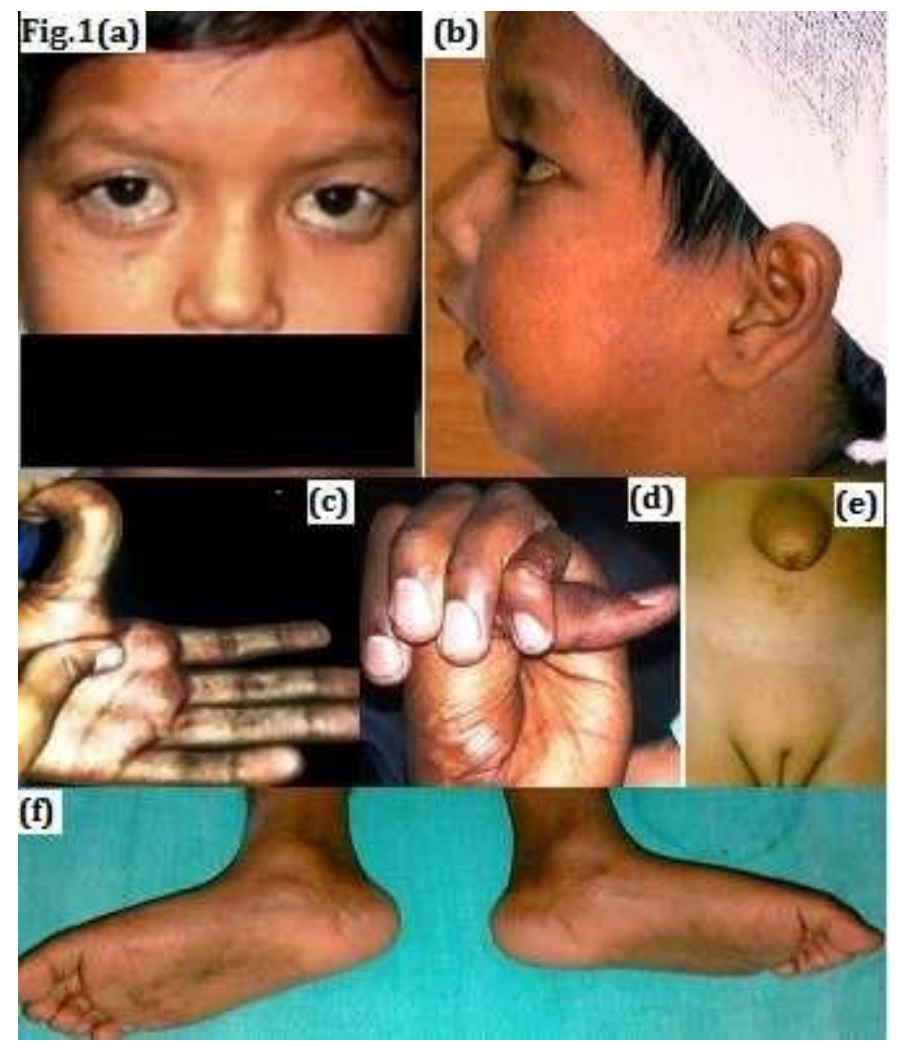

The patient underwent surgical repair for her umbilical hernia with an uneventful post-operative period. She received regular physiotherapy and advice for pes planus and hypotonia. A cardiology consultation for aortic root dilatation was obtained and the patient received prophylaxis for subacute bacterial endocarditis. Speech and language pathologists' referrals were done for speech therapy. Genetic counselling was recommended for the parents; they were advised to visit a genetic clinic that provides information for individuals and families regarding the natural history, treatment, mode of inheritance, and genetic risks to other family members. The parents were advised to bring the patient for regularfollow-ups. 
Table 1: Comparison of clinical findings of Shprintzen-Goldberg syndrome in our index case versus the classical features described by Greally et al. ${ }^{1,4}$

\begin{tabular}{|c|c|}
\hline Classic features of Shprintzen-Goldberg syndrome ${ }^{1,4}$ & Features present in our index case \\
\hline $\begin{array}{l}\text { Craniosynostosis } \\
\text { Usually involves the coronal, sagittal, or lambdoid sutures }\end{array}$ & $\begin{array}{l}\text { Present: Skull radiograph showed flattened cranial } \\
\text { base; signs of craniosynostosis compatible with early } \\
\text { synostosis of the sagittal suture }\end{array}$ \\
\hline $\begin{array}{l}\text { Craniofacial findings } \\
\text { Head : Dolichocephaly with or without scaphocephaly; tall or } \\
\text { prominent forehead } \\
\text { Jaw/mouth and palate : Micrognathia and/or retrognathia; } \\
\text { malar flattening/hypoplasia; high narrow palate with } \\
\text { prominent palatine ridges } \\
\text { Ears : Apparently low-set and posteriorly rotated ears } \\
\text { Ocular : Myopia; telecanthus; hypertelorism; proptosis; } \\
\text { strabismus; down-slanting palpebral fissures }\end{array}$ & $\begin{array}{l}\text { Present: Dolicocephaly } \\
\text { Present: High palate } \\
\text { Present: Low set ears } \\
\text { Present: Hypertelorism; proptosis; downslanting } \\
\text { palpebral fissures }\end{array}$ \\
\hline $\begin{array}{l}\text { Neurologic anomalies } \\
\text { Delayed motor and cognitive milestones } \\
\text { Mild-to-moderate intellectual disability }\end{array}$ & $\begin{array}{l}\text { Present: mental retardation with delayed } \\
\text { developmental milestones }\end{array}$ \\
\hline $\begin{array}{l}\text { Brain anomalies } \\
\text { Hydrocephalus } \\
\text { Dilatation of the lateral ventricles } \\
\text { Chiari } 1 \text { malformation }\end{array}$ & None present or detected until now \\
\hline $\begin{array}{l}\text { Cardiovascular findings } \\
\text { Mitral valve prolapse } \\
\text { Mitral regurgitation/incompetence } \\
\text { Aortic regurgitation } \\
\text { Dilatation of the aortic root }\end{array}$ & Present: Aortic root dilation \\
\hline $\begin{array}{l}\text { Skeletal findings } \\
\frac{\text { Joints: Joint hypermobility or contractures; osteopenia }}{\text { Skull }: \text { Craniosynostosis; wide anterior fontanel_ }} \\
\text { Spine and vertebrae : C1-C2 vertebral abnormality (fusion or } \\
\text { subluxation); scoliosis; square-shaped vertebral bodies } \\
\text { Extremities : Dolichostenomelia; arachnodactyly; } \\
\text { camptodactyly; metatarsus adductus; talipes equinovarus; } \\
\text { pes planus; } \\
\frac{\text { Chest : Pectus excavatum or carinatum; thin ribs; } 13 \text { pairs of }}{\text { ribs }}\end{array}$ & $\begin{array}{l}\text { Present: Hyper extensible thumb; osteopenia } \\
\text { Present: Craniosynostosis } \\
\text { None present or detected until now } \\
\text { Present: Arachnodactyly; talipes equinovarus; pes } \\
\text { planus } \\
\text { Present: } 13 \text { pairs of ribs }\end{array}$ \\
\hline $\begin{array}{l}\text { Genitourinary } \\
\text { External genitalia, male: Inguinal hernia; } \\
\text { Internal genitalia, male: Cryptorchidism } \\
\text { External genitalia, female: Inguinal hernia }\end{array}$ & $\begin{array}{l}\text { Not applicable } \\
\text { Not applicable } \\
\text { Not present }\end{array}$ \\
\hline $\begin{array}{l}\text { Other } \\
\text { Hernias and abdominal wall defects } \\
\text { Loss of subcutaneous fat } \\
\text { Arterial tortuosity and aneurysms } \\
\text { Broad/bifid uvula } \\
\text { Cleft palate } \\
\text { Dural ectasia }\end{array}$ & Present: Umbilical hernia \\
\hline $\begin{array}{l}\text { Molecular genetic testing } \\
S K I \text { is the only gene in which mutations are known to cause } \\
\text { this syndrome }\end{array}$ & $\begin{array}{l}\text { Could not be performed due to poor affordability of } \\
\text { parents }\end{array}$ \\
\hline
\end{tabular}


Mode of Inheritance

Isolated cases
Present

Table 2: Characteristic features of other craniosynostotic syndromes in comparison to our index case

\begin{tabular}{|c|c|}
\hline Loeys-Dietz syndrome (LDS) ${ }^{5,6}$ & $\begin{array}{l}\text { LDS is a recently described autosomal dominant entity characterised by a } \\
\text { triad of arterial tortuosity and aneurysms (cerebral, thoracic, and abdominal } \\
\text { arterial aneurysms and/or dissections), hypertelorism, and bifid uvula or } \\
\text { cleft palate along with skeletal manifestations (pectus excavatum or pectus } \\
\text { carinatum, scoliosis, joint laxity, arachnodactyly, talipes equinovarus). } \\
\text { Occasionally, it could be difficult to clinically differentiate LDS from S-G } \\
\text { syndrome; it was possibly excluded as a diagnosis in our index case due to } \\
\text { the absence of peculiar aneurysms/vascular abnormality that predominantly } \\
\text { exists in LDS. }\end{array}$ \\
\hline Marfan Syndrome ${ }^{7}$ & $\begin{array}{l}\text { Marfan syndrome is an autosomal dominant, systemic connective tissue } \\
\text { disorder characterised by mutation in the FBN1 gene. Patients affected with } \\
\text { this disorder have classical ocular features (myopia; lens dislocation), } \\
\text { skeletal (dolichostenomelia; joint laxity; scoliosis), and cardiovascular } \\
\text { abnormalities (aortic root dilatation; mitral valve prolapse with or without } \\
\text { incompetence; tricuspid valve prolapse; and enlargement of the proximal } \\
\text { pulmonary artery). }{ }^{7} \text { Even though our index case had few overlapping } \\
\text { features like aortic root dilatation and joint laxity, characteristic ocular and } \\
\text { skeletal features of Marfan syndrome were absent. }\end{array}$ \\
\hline 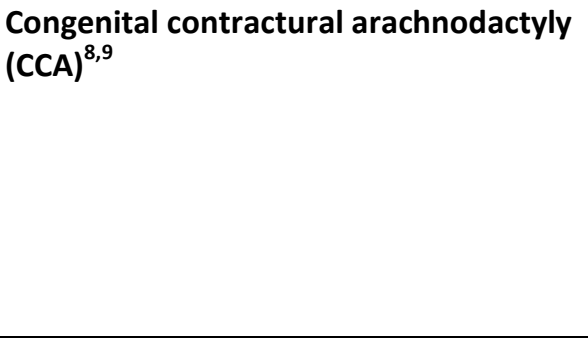 & $\begin{array}{l}\text { Inherited in an autosomal dominant fashion, individuals affected with CCA } \\
\text { have a constellation of clinical findings: abnormal pinna ("crumpled" ears); } \\
\text { flexion contractures of multiple joints at birth; muscular hypoplasia; } \\
\text { kyphoscoliosis; severe form of the disease in infants with multiple } \\
\text { cardiovascular and gastrointestinal anomalies. }{ }^{8,9} \text { CCA has been implicated to } \\
\text { mutations in the FBN2 gene and resembles closely to Marfan syndrome (tall, } \\
\text { slender habitus in which arm span exceeds height and arachnodactyly). The } \\
\text { clinical findings of our case were inconsistent with those described for CCA. }\end{array}$ \\
\hline Frontometaphyseal dysplasia (FMD) $^{10-12}$ & $\begin{array}{l}\text { FMD, one of the otopalatodigital spectrum disorder, it manifests itself as } \\
\text { severe supraorbital hyperostosis, a skeletal dysplasia that includes } \\
\text { campomelia, cortical irregularity and undertubulation of the long bones and } \\
\text { deafness. }{ }^{10-12} \text { Even though FMD shares skeletal findings with S-G syndrome } \\
\text { including tall, square-shaped vertebrae, bowed tibiae, and occasionally, } \\
\text { fusion of upper cervical vertebrae, the presence of intellectual disability and } \\
\text { craniosynostosis usually distinguishes S-G syndrome from FMD. }\end{array}$ \\
\hline Melnick-Needles syndrome (MNS) ${ }^{13,14}$ & $\begin{array}{l}\text { Another otopalatodigital spectrum disorder, MNS is female predominant } \\
\text { and like FMD, intelligence is unimpaired in MNS as well. The affected } \\
\text { females exhibit distinctive dysmorphism (supraorbital hyperostosis, } \\
\text { exorbitism, full cheeks, micrognathia), thoracic hypoplasia due to short, } \\
\text { irregular ribs, pronounced irregularity of the long bones, and long digits }{ }^{13} \text {, } \\
\text { urteric obstruction either at the pelvicaylceal or vesicoureteric junction. }{ }^{14} \\
\text { While MND shares some radiographic similarity with the S-G syndrome, it } \\
\text { can be clinically differentiated by the presence of craniosynostosis and } \\
\text { mental retardation in the latter condition. }\end{array}$ \\
\hline Idaho syndrome-II & $\begin{array}{l}\text { Has less severe craniofacial problems than S-G syndrome and is } \\
\text { accompanied by abnormal leg bones and absent patellae }{ }^{15} \text {. The latter was } \\
\text { absent in the presented case. }\end{array}$ \\
\hline Antley-Bixler syndrome ${ }^{16}$ & $\begin{array}{l}\text { Inherited syndrome with craniofacial abnormalities, abnormal arm and leg } \\
\text { bones, and fractures in the femur. }{ }^{16} \text { These skeletal findings were absent in } \\
\text { our index case }\end{array}$ \\
\hline
\end{tabular}


Figure 2: Radiographic images

(a) Postero-anterior view of the chest showing 13 pair of ribs; (b) Antero-posterior and lateral view (c) of the left foot showing osteopenia, loss of medial arch of the foot/pes planus (d) two-dimensional echo showing marked aortic root dilatation

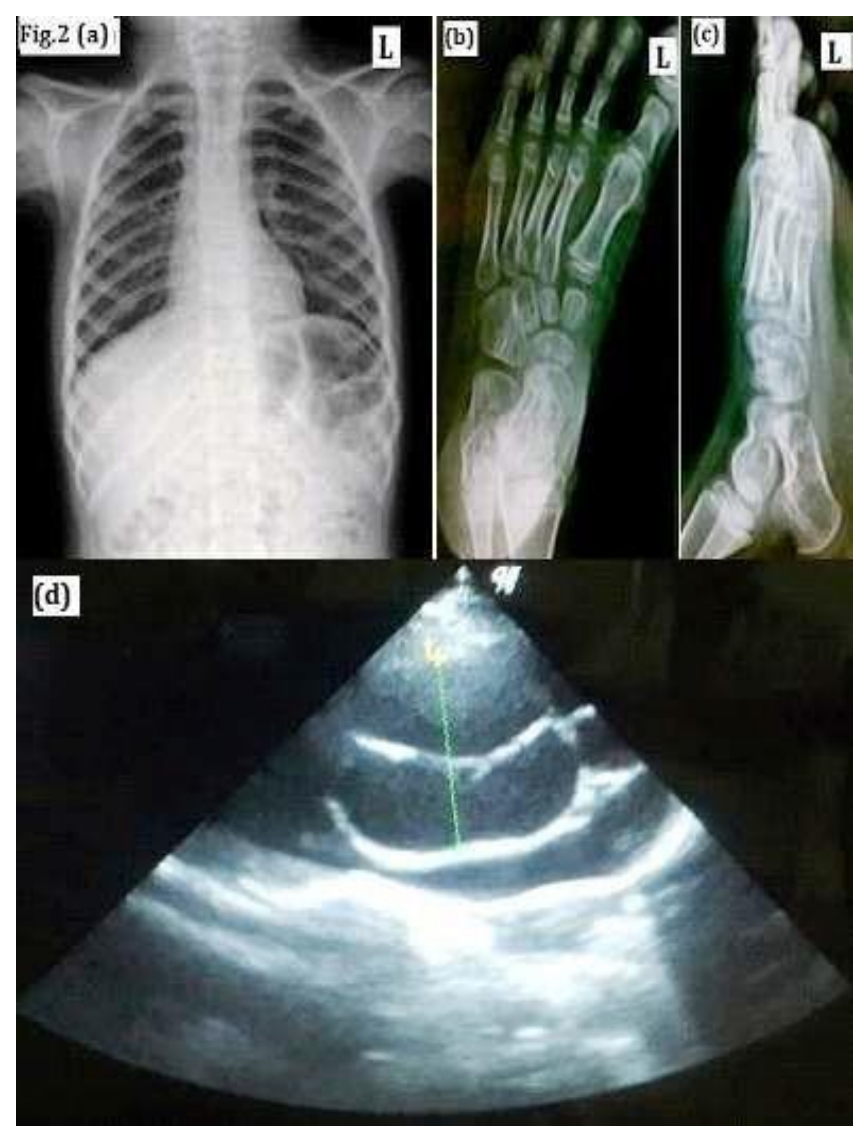

\section{Discussion}

Our case describes the diagnostic dilemma faced in evaluating an Indian child presenting with a congenital umbilical swelling and delayed milestones, and demonstrates the importance of considering abdominal wall defects or umbilical hernia as a presenting feature in patients with Shprintzen-Goldberg syndrome. In addition to a meticulous clinical examination, a high degree of suspicion is critical in corroborating the clinical and imaging findings to that of a classical case described by Greally et al. ${ }^{1,4}$ to diagnose such cases. A careful review of systems and general physical examination along with imaging findings led to the suspicion of and workup for an underlying genetic disorder responsible for the presenting symptoms and the craniofacial dysmorphism. Most of the dysmorphic features present in our index case were consistent with those described by Greally et al. ${ }^{1,4}$ (Table 1 )

Sugarman and Vogel ${ }^{17}$ reported the first case of what is now known as Shprintzen-Goldberg syndrome in a 17-year-old male with plagiocephaly, multiple craniofacial, vertebral and skeletal anomalies, umbilical and inguinal herniae, hypotonia, and mental retardation; however, Shprintzen and Goldberg established this as a separate clinical entity in the year 1982. ${ }^{4}$ Since then, approximately 60 such cases have been documented in medical literature. ${ }^{1,4,5,15,18-24}$ The phenotypic characteristics may be variable and a comprehensive review of clinical analysis of this syndrome has been reported by Greally et al. ${ }^{1,4}$ (Table 1). Although few cases have been attributed to mutation in the fibrillin-1 gene (FBN1) with locus in the long arm of chromosome 15 $(15 q 21.1)^{3,24-26}$, SKI is the only gene in which mutations are known to cause Shprintzen-Goldberg syndrome. ${ }^{4}$ In a recent report describing a Japanese boy with clinical findings consistent with Shprintzen-Goldberg syndrome, Kosaki et al. identified a 3662E-A transition (134797.0045) resulting in cys 1221-to-tyr (C $1221 \mathrm{Y}$ ) substitution in the FBN 1 gene. ${ }^{27}$ Pauliks et al. ${ }^{25}$ reported the first case of complex congenital heart disease in a neonate with Shprintzen-Goldberg syndrome. Likewise, Elmistekawy et al. ${ }^{28}$ descibed the first double valve surgery in a patient with Shprintzen-Goldberg syndrome that presented with increasingly severe mitral regurgitation due to bileaflet prolapse, and tricuspid valve regurgitation. Pavone et al. $^{29}$ reported their findings of a boy aged 16 years, affected by this syndrome that was followed up for 12 years to evaluate the clinical course and underlined the presence of the teeth malformations amongst the various clinical signs of Shprintzen-Goldberg syndrome; fortunately such findings were absent in our patient.

\section{Conclusion}

This case demonstrates diagnosis of Shprintzen-Goldberg syndrome requiring a high degree of clinical suspicion as most of these cases are likely to present with subtle clinical features. Patients with such syndromes can often present to a surgeon with a meagre abdominal wall defect, with umbilical or inguinal hernia as the only presenting complaint. Since such patients may have other systemic abnormalities, including but not limited to, cardiovascular, ophthalmological, radiological, muscular-skeletal, etc., a meticulous clinical examination is essential for its diagnosis and a multi-holistic therapeutic approach is vital for management of such patients. Furthermore, molecular and genetic research is warranted for a better understanding of the disease pathogenesis. With the paucity of literature measuring the magnitude of the condition, this case serves best to promote awareness of this rare entity.

\section{References}

1. Greally MT, Carey JC, Milewicz DM, Hudgins L, Goldberg RB, Shprintzen RJ, et al. Shprintzen-Goldberg syndrome: a clinical analysis. Am J Med Genet 
1998;76(3):202-12.

2. A Topouzelis N, Markovitsi E, Antoniades K. Shprintzen-Goldberg syndrome: case report. Cleft Palate Craniofac J 2003;40(4):433-6.

3. Shprintzen RJ, Goldberg RB. A recurrent pattern syndrome of craniosynostosis associated with arachnodactyly and abdominal hernias. J Craniofac Genet Dev Biol 1982;2:65-74.

4. Greally MT. Shprintzen-Goldberg Syndrome. 2006 Jan 13 [Updated 2013 Jun 13]. In: Pagon RA, Adam MP, Bird TD, et al., editors. GeneReviews ${ }^{\mathrm{TM}}$ [Internet]. Seattle (WA): University of Washington, Seattle; 19932014. Available from: http://www.ncbi.nlm.nih.gov/books/NBK1277/

5. Loeys BL, Chen J, Neptune ER, Judge DP, Podowski M, Holm $T$, et al. A syndrome of altered cardiovascular, craniofacial, neurocognitive and skeletal development caused by mutations in TGFBR1 or TGFBR2. Nat Genet 2005;37:275-81.

6. Loeys BL, Schwarze U, Holm T, Callewaert BL, Thomas $\mathrm{GH}$, Pannu $\mathrm{H}$, et al. Aneurysm syndromes caused by mutations in the TGF-beta receptor. N Engl J Med 2006;355:788-98.

7. Dietz HC. Marfan Syndrome. 2001 Apr 18 [Updated 2011 Dec 1]. In: Pagon RA, Adam MP, Bird TD, et al., editors. GeneReviews ${ }^{\mathrm{TM}}$ [Internet]. Seattle (WA): University of Washington, Seattle; 19932014. Available from: http://www.ncbi.nlm.nih.gov/books/NBK1335/

8. Godfrey M. Congenital Contractural Arachnodactyly. 2001 Jan 23 [Updated 2012 Feb 23]. In: Pagon RA, Adam MP, Bird TD, et al., editors. GeneReviews ${ }^{\mathrm{TM}}$ [Internet]. Seattle (WA): University of Washington, Seattle; 1993-2014. Available from: http://www.ncbi.nlm.nih.gov/books/NBK1386

9. Godfrey M. Fibrillin-2 mutations in congenital contractural arachnodactyly. In: Robinson PN, Godfrey $M$, eds. Marfan Syndrome: A Primer for Clinicians and Scientists. New York, NY: Plenum; 2004:123-9.

10. Gorlin RJ, Cohen Jr MM: Frontometaphyseal dysplasia. A new syndrome. Am J Dis Child 1969;118:487-494.

11. Danks DM, Mayne V: Frontometaphyseal dysplasia: a progressive disease of bone and connective tissue. Birth Defects Orig Artic Ser 1974; 10: 57-60.

12. Holt JF, Thompson GR, Arenberg IK: Frontometaphyseal dysplasia. Radiol Clin North Am 1972;10:225-243.

13. Melnick JC, Needles CF: An undiagnosed bone dysplasia. A 2 family study of 4 generations and 3 generations. Am J Roentgenol Radium Ther Nucl Med 1966;97:39-48.
14. LaMontagne AE: Urological manifestations of the Melnick-Needles syndrome: a case report and review of the literature. J Urol 1991;145:1020-1021.

15. Stoll C. Shprintzen-Goldberg marfanoid syndrome: a case followed up for 24 years. Clin Dysmorphol 2002;11(1):1-7.

16. Antley R, Bixler D. Trapezoidocephaly, midfacial hypoplasia and cartilage abnormalities with multiple synostoses and skeletal fractures. Birth Defects Orig Artic Ser. 1975;11(2):397-401.

17. Sugarman G, Vogel MW. Craniofacial and musculoskeletal abnormalities. A questionable connective tissue disease. Synd Iden 1981;7:16-7.

18. Ades LC, Morris LL, Power RG, Wilson M, Haan EA, Bateman JF, et al. Distinct skeletal abnormalities in four girls with Shprintzen-Goldberg syndrome. Am J Med Genet 1995;57:565-72.

19. Saal HM, Bulas DI, Allen JF, Vezina LG, Walton D, Rosenbaum KN. Patient with craniosynostosis and Marfanoid phenotype (Shprintzen-Goldberg syndrome) and cloverleaf skull. Am J Med Genet 1995;57:573-8.

20. Seemanova E, Kozlowski K. Shprintzen-Goldberg syndrome: A case report. Radiol Med 1997;94:673-75.

21. Adachi M, Tachibana K, Asakura Y, Suwa S, Nishimura G. A male patient presenting with major clinical symptoms of glycocorticoid deficiency and skeletal dysplasia, showing a steroid pattern compatible with 17alpha-hydroxylase/17,20-lyase deficiency, but without obvious CYP17 gene mutations. Endocr J 1999;46:285-92.

22. Brooks AS, Breuning $\mathrm{MH}$, Osinga J, vd Smagt JJ, Catsman $\mathrm{CE}$, Buys $\mathrm{CH}$, et al. A consanguineous family with Hirschsprung disease, microcephaly, and mental retardation (Goldberg-Shprintzen syndrome). J Med Genet 1999;36:485-9.

23. Robinson PN, Neumann LM, Demuth S, Enders H, Jung $U$, König $R$, et al. Shprintzen-Goldberg syndrome: fourteen new patients and a clinical analysis. Am J Med Genet 2005;135(3):251-62.

24. Sood S, Eldadah ZA, Krause WL, Mclntosh I, Dietz HC. Mutation in fibrillin-1 and the Marfanoidcraniosynostosis (Shprintzen-Goldberg) syndrome. Nat Genet 1996;12(2):209-11.

25. Pauliks LB, Chan KC, Lorts A, Elias ER, Cayre RO, ValdesCruz LM. Shprintzen-Goldberg Syndrome With Tetralogy of Fallot and Subvalvar Aortic Stenosis. J Ultrasound Med 2005;24(5):703-6.

26. Hayward C, Brock DJ. Fibrillin-1 mutations in Marfan syndrome and other type-1 fibrillinopathies. Hum Mutat 1997;10(6):415-23.

27. Kosaki K, Takahashi D, Udaka T, Kosaki R, Matsumoto 
$M$, Ibe $S$, et al. Molecular pathology of ShprintzenGoldberg syndrome. Am J Med Genet 2006;140(1):104-8.

28. Elmistekawy E, Hudson CC, Williams A, Mesana T. Double-valve surgery in Shprintzen-Goldberg syndrome. Asian Cardiovasc Thorac Ann. October 9, 20130218492313485070

29. Pavone V, Leonardi R, Sorge G, Pavone P, Pratico A, Sessa G. A patient with Shprintzen Goldberg syndrome. Clinical follow-up for twelve years. J Pediatr Sci. 2012;4(4):e164.

\section{AUTHOR'S CONTRIBUTION}

$\mathrm{BS}$ and MS participated in the clinical diagnosis, patient care and follow-up. BS and MS were the operating team of surgeons. SS and PK contributed to sequence alignment whereas SS and SY were involved in drafting of the manuscript. SS and VBB made useful contributions to the review of the literature. SS, PK and VBB participated in writing the discussion section. PK and MMAS helped revise the manuscript. All authors read and approved the final manuscript.

\section{PEER REVIEW}

Not commissioned. Externally peer reviewed.

\section{CONFLICTS OF INTEREST}

The authors declare that they have no competing interests.

\section{ETHICS COMMITTEE APPROVAL}

Not applicable for a case study

\section{PATIENT CONSENT}

The authors, Bhushan Shah and Meena Shaikh, declare that:

1. They have obtained written, informed consent for the publication of the details relating to the patient in this report.

2. All possible steps have been taken to safeguard the identity of the patient.

3. This submission is compliant with the requirements of local research ethics committees. 